\title{
An assessment of simultaneous attainability of internal and external economic stability: Evidence from Nigeria
}

\author{
Francis A. Olueye $\mathrm{a}^{*}$ \\ ${ }^{a}$ Economics and Development Program, Federal University Otuoke, Bayelsa. \\ *Corresponding author's e-mail:francisoluleye@yahoo.com
}

H I G H L I G H T S:

1. There are divergent views on the possibility of achieving internal and external balances simultaneously.

2. The same variables can affect internal and external balances but in different directions.

3. Exchange rate is significant in achieving both internal and external balances.

4. The depreciation of the Nigeria's naira has boosted domestic income but worsened the current account.

5. Priority attention should be given to internal balance which has more direct impact on people's welfare.

\begin{tabular}{|c|c|}
\hline Article History & ABSTRACT \\
\hline $\begin{array}{l}\text { Received:27-07-2014 } \\
\text { Accepted: } 10-08-2014 \\
\text { Available online: } 12-08-2014 \\
\text { Keywords: } \\
\text { Balance of payments; } \\
\text { Economic growth; } \\
\text { Inflation; } \\
\text { Unemployment; } \\
\text { Stability. }\end{array}$ & $\begin{array}{l}\text { This study set out to investigate whether it is possible to simultaneously achieve internal } \\
\text { and external economic stability objectives and to examine the impact of economic stability } \\
\text { on economic growth. A model of simultaneous relation was formulated and identified. Data } \\
\text { covering } 1970-2012 \text { were collected and the technique of Indirect Least Squares (ILS) was } \\
\text { applied to analyze the data. The study found that there is a trade-off relationship between } \\
\text { internal stability and external balance. Achieving external balance is therefore at the } \\
\text { expense of internal balance. There is, thus, the need for government to choose between } \\
\text { achieving internal balance or external balance. It is therefore the recommendation of this } \\
\text { paper that priority attention should be given to internal stability. }\end{array}$ \\
\hline
\end{tabular}

JEL Classification:

E20; E63; F32; 011.

DOI: http://dx.doi.org/10.18533/jefs.v2i03.79

(C) 2014 The Authors. This is an open access article under the terms of the Creative Commons Attribution License 4.0, which allows use, distribution and reproduction in any medium, provided the original work is properly cited.

\subsection{Introduction}

An economy strives to achieve both microeconomic and macroeconomic objectives. The microeconomic objectives are efficiency in production and equity in income distribution. The macroeconomic objectives are attainment of full employment, price stability, economic growth and balance of payments (BOP) equilibrium. A nation is usually faced with two types of stability challenges- internal stability and external stability. Internal stability challenge has to do with how a nation ensures that people who are willing and have the ability to work get job and that the general price level is kept relatively stable. These are the two serious economic problems that can cause unrest among the people. Their impact is directly felt by everyone in that country. The success of a government is also usually measured by the people using the extent to which these two problems are solved as a yardstick. Any nation that can put these two problems at the barest minimum will have relative stability in its internal economic system.

External stability challenge has to do with how to manage the relationship between imports and exports of a nation to achieve favourable balance of payments. Theoretically, the objective is to achieve balance of payments equilibrium but practically, the desire of any nation is to secure surplus in the current account. When current 
account is in disequilibrium, that is surplus (when exports exceed imports) or deficit (when imports exceed exports), something has to be done to correct the situation. A current account surplus can be corrected by increasing the country's foreign assets. Current account deficit, on the other hand, can be corrected by selling foreign assets, or external borrowing. A country can be said to be suffering from external instability if it records persistent deficits in the current account.

In the 1960s' and early 1970s', Nigeria could be said to experience relative internal and external stability. Unemployment and inflation did not pose serious challenge and we did not also see the level and rate of economic growth as unsatisfactory. Also, because of the level of development and state of technology in the country, imports were moderate. As a result, exports (of agricultural products and crude oil) surpassed imports. Therefore, the BOP was favourable. But since the mid-1970s', the situation changed. The emerging and growing manufacturing and production sectors in the country were largely import dependent. This, coupled with increased propensity for consumption of imported goods by Nigerian residents, shot up import bills for the country. To further aggravate the situation, there was increasing neglect of the agricultural sector and the world oil market collapsed in 1981. The consequence was that from around mid-1970s', current account deficits became obvious, pronounced and chronic. Initially, it was expected that the deficits in the current account would short-live. Therefore, the response to this was in the form of trade and exchange control measures. These measures were made stringent and pervasive between 1982 and 1985. This era also witnessed over-valuation of the naira. Although these measures yielded some positive results by reversing the trend of current account deficits, it became clear, in 1985, that the country needed structural re-adjustment of the economy. This realization gave birth to the structural adjustment programme (SAP) in 1986. The programme succeeded in endearing Nigeria's imports and thereby reducing imports bill substantially. But the inability to stimulate or promote the country's exports coupled with the overvaluation of the naira as well as inability to source raw materials locally by the manufacturing sector dislocated the internal economic system. Hence it threw the nation into internal instability. As result of high cost of raw materials (imported raw materials), manufacturing companies began to operate below installed capacity resulting in laying off of their workers, culminating in increasing level of unemployment. More so, the reduction in the supply of goods (as a result of high cost of production) relative to demand, put upward pressure on the price level manifesting in inflation. Hence, the bid to secure stability in our external sector (i.e. favourable or equilibrium BOP) created internal instability.

This paper, therefore, sets out to examine the possibility of achieving internal and external stability simultaneously for a country, the extent of trade-off relationship between internal and external stability, and relative impact of internal and external stability on economic growth.

In order to achieve the above objectives, the paper is structured into five sections. Section 1 is the introduction which gives the background to the study. Section 2 reviews relevant literature and gives the theoretical framework. Section 3 discusses the materials and methods used in the study. Section 4 presents, analyses and discusses the estimated results, while section 5 concludes the work.

\subsection{Literature review and theoretical framework}

The relationship between key economic factors has a particularly important influence on government decision making which ultimately affects the wellbeing of the residents of the country. The achievement of internal and external stability will, in no doubt, stimulate economic growth and improve the wellbeing of the people in that country.

\subsection{Internal stability}

Internal stability is achieved when production (total output) is equal to absorption (domestic expenditure). At that point, full employment and price stability are achieved. According to the Income-Absorption theorists, when production is greater than absorption, unemployment results. And when absorption exceeds production, inflation results, According to this view, unemployment and inflation, which are the two major economic problems causing internal instability are as a result of production not being equal to absorption. Keynes (1936) shared this view when he said unemployment results from deficient demand and therefore called on the government to stimulate demand with the use of fiscal policy.

Unemployment implies underutilization of factors of production. As noted by Oluleye (2005), although any factor of production can be unemployed, attention is usually focused on labour unemployment because of its economic, political and socio-cultural implications. If a man who is willing, able and seeking to work cannot get a job, he has the tendency to engage in criminal activities or other social vices in order to survive unlike in the case of other factors. 
The major implication of inflation is that it reduces the purchasing power of money. And if this happens, people's confidence in money will be lost. The loss of confidence of the people in money will definitely result in it losing its ability to perform its functions. As observed by Oluleye (2005), it portends a serious threat to economic growth considering its effects on voluntary savings, productive investment, Balance of payments and its use as a medium of exchange.

\subsection{Unemployment and inflation}

A person is defined as being unemployed if he or she does not have a job but is available for work, is willing to work and has made some effort to find work within the previous four weeks (Parkin, 1998). Classical economists argued that unemployment exists when unions maintain wages above the equilibrium level. When this happens, we have a situation of involuntary unemployment. This implies that to solve unemployment problem, it is simply to remove the artificial ceiling placed by the unions. In the view of Keynesians, unemployment results from deficient demand. Demand deficiency or cyclical unemployment is the disequilibrium level of involuntary unemployment caused by the combination of low aggregate demand and sluggish wage adjustment. Keynesian unemployment is that part of total unemployment that the government could help to mop up by using fiscal and monetary policies to boost aggregate demand. Employment and unemployment in developing countries have been the concern in recent years to the extent that international labour office has sponsored missions to several countries to undertake detailed analysis as part of the world's employment programme.

Parkin (1998) defined inflation as a process of rising prices. According to Begg (1994), inflation is a persistent rise in the average price of goods overtime. The lives of all citizens are affected by inflation. Uncontrolled inflation can dislocate the economy and cause social upheaval. The evils of inflation are subtle (Udu and Agu, 1989). Bello (1999) noted that inflationary situation has become more and more frustrating in the developing economies. More recently however, issues relating to government policy decision are beginning to gain ground as an illusive factor causing inflation. Bello (1999) and Johnson (1972) see inflation as a sustained rising trend in the general price level. On the part of Solow (1969), inflation is going on when ones needs more and more money to buy same representative bundle of goods and services or a sustained fall in the purchasing power of money.

A major mechanism suggested by contemporary economists to curb inflation is the reduction in government expenditure. In other words, government should adopt contractionary fiscal and monetary policies. On the other hand, expansionary fiscal and monetary policies are recommended for tackling unemployment. As Oluleye (2005) observed, there seems to be a perfect contradiction in these recommendations. In his words, "given that the economies of developing countries are bedeviled with these two problems simultaneously, an appropriate mix of these two policies constitutes a big challenge to the policy makers". In the face of this trade-off relationship between inflation and unemployment, it is better to give priority attention to solving unemployment problem. The trade-off relationship is a short run phenomenon. Hence, to have internal stability in the economy, everybody willing and able to work should get job.

\subsection{External stability}

Equality between exports and imports of goods and services or favourable (surplus) current account balance implies external stability. While deficits in the current account will call for government making frantic efforts to reverse the trend, surplus will only call for sustenance policies. The current account section in the Balance of payment (BOP) is the record of the monetary value of international trade. There is no country in the world that exists in isolation. Every country buys goods produced in other countries and sells what it produces to other countries.

Periodically, a country usually examines what it sold out and what it bought in during a particular period. This examination is done using a record called the Balance of payments (BOP). According to Akpakpan in Gbanador (2005), the BOP is a systematic record and summary of all economic transactions that take place between the residents of the reporting country and the residents of all other foreign nations of the world for a time period. The BOP has three main parts: the current account, capital account and monetary movements. As noted by Gbanador (2005) every entry in the BOP usually carries either a positive or negative sign. A positive sign shows an inflow of foreign currencies indicating the value of goods and services exported while a negative sign shows an outflow of foreign currencies indicating the value of imports. According to him, a country is said to have a deficit in its BOP if it has recorded a negative overall balance for the period. But if it has recorded a positive overall balance, it is said to have a surplus in its BOP. If the value of imports exactly equals the value of exports, the country's BOP is said to be in equilibrium. The desire of every country is that what was sold out (exports) should be more than what was brought in (imports) so that there can be surplus or at least make exports and imports equal. Policies of government are usually directed at ensuring that there is surplus or at least equilibrium in the BOP. It is when this is achieved that external stability is said to exist. 
Deficits in the current account are a source of worry to any government. It simply implies that that country is externally unstable. Measures are therefore put in place to correct the external instability. Two main policy methods have been recommended to correct the deficits in the current account. These are reduction in government expenditure (expenditure reducing policy) and devaluation of the nation's currency (expenditure switching policy). Reduction in government expenditure will reduce the income of the residents and consequently, their ability to demand for imports. Devaluation has the effect of endearing imports and hence discouraging importation. In addition, it is expected that devaluation will stimulate exports. All this will combine to improve BOP position.

\subsection{Internal and external stability}

The issue has been whether both internal and external stability are achievable simultaneously. Are full employment, price stability and favourable Balance of payment objectives congruent? As many studies have shown, like that of Oluleye (2005), there is a trade-off relationship between inflation and unemployment, although such relationship is a short run phenomenon. Can full employment and favourable BOP or price stability and favourable BOP be achieved simultaneously? Many writers are of the view that simultaneous achievement of favourable BOP and full employment or favourable BOP and price level stability is possible. They recommended the use of complimentary policies to generate both internal and external balance. The proponents of this approach include Mundell (1951) and Meade (1951). Meade (1951) emphasised the use of fiscal and monetary measures in controlling domestic expenditure on one hand and devaluation for regulating the allocation of domestic and foreign output on the other hand. He wanted the objectives of BOP equilibrium, full employment and price stability to be reconciled and achieved. This necessitates the use of available policy tools to regulate the levels of money wage rate and foreign exchange. To this extent, Meade (1951) urged the IMF and the World Bank to use variations in exchange rates between national currencies coupled with free trade and payments as foreign exchange policies. In the view of Jimoh (1989), fiscal and monetary policy mix should be blended together for external and internal balances while domestic foreign price ration be reduced. Johnson (1972) however disagreed with the view that a policy combination can achieve both internal and external balances simultaneously. He noted that such view is dogmatically based on the classical adjustment and transfer analysis. He doubted if such analysis would work in developing countries. In his words, it is".... doubtful (if that) will operate in developing nations where market imperfections and rigidities are rampant".

\subsection{Theoretical framework}

The two main macroeconomic stability goals are internal and external balances. Internal balance refers to a situation in which a country fully employs its resources and domestic price levels are stable. In this situation, the economy is said to be at its potential level of output. External balance is a situation in which a country has equilibrium in its current account or has surplus in its current account. That is, autonomous exports are equal to or greater than autonomous imports. To achieve internal and external balances, two separate policy measures are required. They are usually categorised into expenditure changing and expenditure switching policies. Expenditure changing policy, which is in the form of monetary and fiscal policies, affects income and employment with a view to equate absorption (domestic expenditure) and production. Expenditure switching policy (e.g. devaluation) on the other hand, alters the relative expenditure on foreign and domestic goods. It directly impacts on the current account balance.

Keynesian national income model can be used to depict the interaction between internal and external balances. Keynes (1936) specified disposable income $\left(\mathrm{Y}^{\mathrm{d}}\right)$ as the explanatory variable of consumption (C) i.e.C $=\mathrm{C}\left(\mathrm{Y}^{\mathrm{d}}\right)$.He specified real exchange rate and disposable income as variables explaining the behaviour of the current account section of balance of payments. i.e.CA $=\mathrm{CA}\left(\mathrm{ER}_{\mathrm{r}}, \mathrm{Y}^{\mathrm{d}}\right)$. Where $\mathrm{CA}$ implies current account balance (or trade balance); $E R r$, the real exchange rate and $Y^{d}$, disposable income.

Deriving from Income-Absorption theory as proposed by Alexander (1952), internal stability is achieved when absorption (domestic expenditure) is equal to production. Inflation results when absorption is greater than production. Conversely, unemployment results when production is greater than absorption. Hence the two problems of unemployment and inflation are the result of inequality of production and domestic expenditure. Production (or income) refers to monetary value of all goods and services produced in an economy during a period of time while absorption is the total expenditure (demand) of the various sectors of the economy. In the case of external stability, exports are expected to be equal to imports. Where exports exceed imports, there is trade surplus. And where imports exceed exports, there is trade deficit. Trade Balance is therefore expected to be zero.

\subsection{Methods and materials}

\subsection{Formulation and specification of the model}


From the Income-Absorption theory, we can conclude that, income = absorption. Alternatively, $\mathrm{Y}=\mathrm{A}$. Where $\mathrm{Y}=$ national income and $\mathrm{A}=$ domestic expenditure.

In an open economy, like Nigeria, 'A' is made up of domestic expenditure of households (C), firms (I), government $(\mathrm{G})$, and foreigners i.e exports $(\mathrm{X})$.

Hence,

$$
\mathrm{Y}=\mathrm{C}+\mathrm{I}+\mathrm{G}+\mathrm{X}
$$

If we decide to use net exports, then the above equation becomes:

$$
\begin{aligned}
& Y=C+I+G+X-M: \\
& \text { where: } \\
& C=C_{0}+C_{1} Y-C_{2} i^{*} \\
& I=I_{0}+I_{1} Y-I_{2} i \\
& G=G^{0} \\
& X=X_{0}+X_{1} e \\
& M=M_{0}-M_{1} e+M_{2} Y \\
& X-M=\text { current account balance }
\end{aligned}
$$

Here we state that consumption depends not only on current income but also on interest rate because in most poor nations including Nigeria, a large proportion of private consumption is financed through borrowing or credit facility due to too low level of income. Investment depends on both level of income and interest rate. Government expenditure is exogenously determined. Export is determined mainly by exchange rate. Foreign income is assumed to be constant. Imports depend on exchange rate and level of national income. Hence, it is theoretically expected that:

$$
\mathrm{C}_{1}>0, \mathrm{C}_{2}<0, \mathrm{I}_{1}>0, \mathrm{I}_{2}<0, \mathrm{X}_{1}>0, \mathrm{M}_{1}<0, \mathrm{M}_{2}>0
$$

The Reduced-form equation becomes:

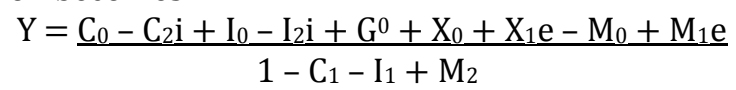

Where,

Hence,

$C_{0}, C_{1}, C_{2}, I_{0}, I_{1}, I_{2}, X_{0}, X_{1}, M_{0}, M_{1}, M_{2}$ are parametric coefficients.

$$
\begin{aligned}
& \mathrm{Y}=\mathrm{f}(\mathrm{i}, \mathrm{e}, \mathrm{u}) \quad \text { (internal stability function) } \\
& \text { Where } \partial \mathrm{Y} / \partial \mathrm{i}<0, \partial \mathrm{Y} / \partial \mathrm{e}>0, \mathrm{E}(\mathrm{u})=0
\end{aligned}
$$

For external stability

Exports should be equal to imports

i.e $\quad \operatorname{Exports}(\mathrm{X})=\operatorname{Imports}(\mathrm{M})$

$$
\Rightarrow \mathrm{X}-\mathrm{M}=0
$$

i.e Current account balance $(\mathrm{CA})=0$

But $\mathrm{X}=\mathrm{f}(\mathrm{e})$, if foreign income is assumed to be constant

Where $\mathrm{e}=$ exchange rate

And

$\mathrm{M}=\mathrm{f}(\mathrm{Y}, \mathrm{e})$

Hence,

Where $\mathrm{Y}=$ domestic national income

$$
\mathrm{CA}=\mathrm{f}(\mathrm{e}, \mathrm{Y}, \mathrm{u}) \quad \text { (external stability function) }
$$

Where $\partial \mathrm{CA} / \partial \mathrm{e}>0, \partial \mathrm{CA} / \partial \mathrm{Y}<0$ and $\mathrm{E}(\mathrm{u})=0$

To have both internal and external stability, we shall equate internal and external stability functions

i.e $\quad \Pi=\mathrm{IEB}=\mathrm{Y}=\mathrm{CA}$

$» \quad \prod=\mathrm{f}(\mathrm{i}, \mathrm{e}, \mathrm{u})=\mathrm{f}(\mathrm{e}, \mathrm{Y}, \mathrm{u})$

Where $\Pi=\mathrm{IEB}=$ internal-external balance

Our model therefore becomes:

$$
\begin{array}{lc}
\mathrm{Y}=\mathrm{f}(\mathrm{i}, \mathrm{e}, \mathrm{u}) & \text { - internal balance } \\
\mathrm{CA}=\mathrm{f}(\mathrm{e}, \mathrm{Y}, \mathrm{u}) & \text { - external balance } \\
\Pi=\mathrm{Y}=\mathrm{CA} & \text { - internal-external balance }
\end{array}
$$

The above model reflects a system of simultaneous relation because $\mathrm{Y}$ is both a dependent and independent variable in the model. In order to deal with this kind of relations, we must identify the status of the model. The identification is contained in the appendix. 
In order to satisfactorily generate the parameters of exactly identified model, Indirect Least Squares (ILS) method is the most appropriate. ILS is a single equation method. According to Koutsoyannis (1979), it is appropriate when the equations of the structural system contain both predetermined and endogenous variables among the set of explanatory variables, provided that the equations of the system are exactly identified. The principle in ILS is that Ordinary Least Squares (OLS) is applied to the reduced-form equation from the structural equations. The reduction is done in such a way that the dependent variables are expressed as functions of the predetermined variables and the stochastic error (disturbance) term.

Hence, our structural equations above can be reduced as follows:

Recall that,

$$
\begin{aligned}
& \mathrm{Y}=\mathrm{Y}_{0}-\mathrm{Y}_{1} \mathrm{i}+\mathrm{Y}_{2} \mathrm{e}+\mathrm{u}_{1} \ldots \ldots \ldots \ldots \\
& \mathrm{CA}=\mathrm{CA}_{0}+\mathrm{CA}_{1} \mathrm{e}-\mathrm{CA} 2 \mathrm{Y}+\mathrm{u} 2 \\
& \Pi=\mathrm{Y}=\mathrm{CA}
\end{aligned}
$$

This becomes:

$$
\begin{aligned}
& \mathrm{Y}=\prod_{10}+\prod_{111} \mathrm{i}+\prod_{12} \mathrm{e}+\mathrm{Vt} \\
& \mathrm{CA}=\prod_{20}+\prod_{21} \mathrm{i}+\prod_{22} \mathrm{e}+\mathrm{Wt} \\
& \begin{array}{ll}
\text { Table 01: Variables in the model to be estimated } \\
\hline \text { Symbol } & \text { Variable } \\
\hline \mathrm{Y} & \text { Domestic national income } \\
\hline \mathrm{i} & \text { Lending interest rate } \\
\hline \mathrm{e} & \text { Exchange rate }(\mathrm{N} / \$) \\
\hline \mathrm{CA} & \text { Current account balance }
\end{array}
\end{aligned}
$$

Note: $\Pi_{10}-\Pi_{22}$ imply parametric coefficients

\subsection{Result and discussion}

\begin{tabular}{|c|c|c|c|}
\hline \multicolumn{4}{|c|}{ Dependent variable: Y (Observation from 1970 - 2012) } \\
\hline & Coentcient & $1-v a d u e$ & P-value \\
\hline e & $62365.77^{*}$ & 9.513 & 0.000 \\
\hline i & -39687 & -0.964 & 0.342 \\
\hline Constant & 233275.85 & 0.370 & 0.714 \\
\hline
\end{tabular}

The model above is evaluated using the following criteria: (1) apriori expectations about the signs; (2) test of significance of parameter estimates using T-statistic, (3) goodness of Fit - test, R2 , and finally (4) adequacy of

\begin{tabular}{|c|c|c|c|}
\hline \multicolumn{4}{|c|}{ Table 3: Estimated Internal Stability model } \\
\hline Regressors & Coefficient & T-value & P-value \\
\hline $\mathrm{e}$ & $12303.5^{*}$ & -10.71 & 0.000 \\
\hline Y & $0.325^{*}$ & 24.10 & 0.000 \\
\hline Constant & 27766.46 & 0.680 & 0.501 \\
\hline
\end{tabular}
regression equation, F-test

\subsection{The data}

Time series data were collected for the period 1970 - 2012 denoting a period of 38 years. The sources of the data are (1) central bank of Nigeria statistical bulletin (various volumes), (2) central bank of Nigeria annual reports and statement of accounts (2012), and finally (3) National Bureau of Statistics Annual Abstract of Statistics (2010),

\subsection{Estimated results}

By using indirect least squares method to the reduced-form equations and transforming back to the original equations, the following results were obtained:

Note: The asterisk $\left(^{*}\right)$ indicates that the coefficient is significant while the values in the parentheses are the p-values) 
Our results in table 2 above show that there is a positive relationship between domestic output or income and exchange rate and negative relationship between domestic income and interest rate. Both the exchange rate and interest rate variables meet the signs apriori expectations. The coefficient of determination which measures the goodness of fit model shows that about 76 percent of the variations in the dependent variable is explained by the explanatory variables. The F-value of 51.81 shows that the overall model is adequate at 5 percentage level. For the internal balance model, only exchange rate is significant at 5 percentage level.

For the external balance model, our results in table 3 reveal that about 96 per cent of the variations in the dependent variable are explained by the independent variables. The F-value of 429.64 also shows that the overall model is adequate at 5 percentage level. Although both exchange rate and domestic income variables did not meet the sign expectation respectively, they are significant at less than 1 percentage as judged by the t-values.

\subsection{Discussion of findings}

The significance and meeting of sign expectation of exchange rate variable in the internal balance model implies that continuous devaluation or depreciation of the naira increases domestic income. This is because devaluation or depreciation of naira will discourage imports and/or increase exports. Even if currency depreciation cannot increase exports due to supply rigidities, as is the case with most LDCs, it will, at least, discourage and reduce imports as has been experienced in Nigeria, thereby curtailing outflow of the nation's resources. This reduction in imports will alter the relationship between exports and imports in favour of domestic income as resources that would have been expended on imports would be conserved and used domestically. In addition, imports-substitutes' industries will then thrive generating employment and creating income for the people. More so, increase in exchange rate (i.e. depreciation or devaluation) encourages inflow of foreign resources in form of home remittances by nationals residing abroad as well as investment capital. All these combine to increase domestic income. This increase in national income therefore signifies economic growth. Thus depreciation of currency is significant in enhancing economic growth.

Increased national income will, in turn, generate more employment and since the economy may be operating at less than full employment may not result in inflation. Although interest rate variable does not have significant effect on domestic national income, our results show that when interest rate in the economy rises, national output will be lowered. This is because both investment and consumption expenditures will be discouraged.

In the case of external balance, the significance of both exchange rate and domestic income variable imply that both of them have significant effect on the current account balance. This means that the levels of exchange rate and domestic income determine whether there will be surplus, deficit or equilibrium in the current account. But unfortunately, the two variables did not meet the signs expectation. In other words, we found that an increase in exchange rate (as a result of devaluation or depreciation of the domestic currency) will worsen the current account position. The implication of this is that a policy of devaluation or depreciation of currency cannot improve the current account in Nigeria. Marshall and Lerner in Levacic and Rebmann (1982) noted that for devaluation to improve current account, the sum of the elasticities for the demand for imports and exports should be greater than one (ex+ $\left.e_{M}>1\right)$. It is however doubtful if this can happen in developing countries where there are supply and structural rigidities. Hence, devaluation may rather worsen the current account. In the case of income, it is expected that an increase in domestic income will worsen the current account balance. This expectation is intuitively based on the assumption that extra households' incomes would be expended on foreign goods. However, our results point to the contrary. The reasoning behind the positive relationship between current account balance and domestic national income is that because people are living in abject poverty, any increase in their income will be spent on basic necessities without necessarily being spent on imported goods.

From our findings and discussions, exchange rate variable is significant in attaining internal and external balances. Variations in exchange rate can improve or dislocate the economy. Both internal and external stability enhance economic growth. However, the policies directed at ensuring external stability in Nigeria will destabilise internal balance. Devaluation (or depreciation of the naira) for instance, will increase domestic national income and generate employment because resources that would have been expended on imported goods will now be used locally which will generate employment and further increase income. But as we saw in our analysis, devaluation will worsen the current account, because given the nature of the economies of developing nations; manufacturing sector is import dependent for its inputs and supply of export products is very rigid. Hence it is difficult to achieve both internal and external stability judging from our analysis using Nigerian data.

\subsection{Conclusion and policy implications}

Our study has shown that exchange rate is very significant in attaining both internal and external stability. Both internal and external stability enhance economic growth. However, given the nature of the economies of developing 
nations like Nigeria, it is difficult to achieve both internal and external stability simultaneously. This finding lends credence to the finding of Johnson (1972) that it is difficult to achieve internal and external balances simultaneously as such possibility is dogmatically based on the classical adjustment and transfer analysis which is unlikely to work in developing countries. The fluctuating and continued depreciation of the naira vis-à-vis the US dollar has impacted significantly on the economy.

To this end, the following recommendations are made. First, since there is a trade-off relationship between internal and external stability, priority attention should be given to ensuring internal stability. This is because internal stability or balance has more direct impact on the welfare of the people. Increased employment directly provides income to the people. Second, the current policy of exchange rate deregulation, even though it has not improved the BOP significantly because of exports rigidities, should be sustained as it will continue to discourage imports and direct the attention of Nigerians towards searching for local substitutes. In addition, our analysis showed that devaluation/depreciation of naira increases domestic income which will, in the long run accelerate economic growth. Third, efforts should be intensified to enhance exports of goods and services. The economic base of the nation should be diversified. A situation in which the nation is depending on only one product for export is worrisome and calls for urgent attention. There are potentials in agriculture and solid minerals. These potentials should be exploited. Finally, since interest rate is negatively related to national output and hence economic growth, interest rate should be lowered to encourage investment but not too low as to cause financial repression. To this end, monetary authorities should determine the appropriate level of interest rate in the economy. This can be done by examining a number of factors influencing the interest rate.

\section{References}

Alexander, S.S., 1952. Effects of devaluation on a trade balance. In S.S.Alexander (ed) Readings in International Economics, England, McGraw-Hill Publishing Company, http://dx.doi.org/10.2307/3866218

Begg D., 1994. Economics, England, McGraw-Hill Publishing Company

Bello R.A., 1999. The determinants of inflation in Nigeria (1970-1996), Ilorin Journal of Business and Social Sciences, 6(1): 147-158

Central Bank of Nigeria, 2006. Annual report and statement of accounts, Abuja, CBN

Gbanador, C.A., 2005. Devaluation and balance of payments stability in an oil producing economy:Lessons from Nigeria's experience (1986 - 2003). Nigerian Journal of Monetary Economics, 5(4-5): 118 - 131.

Jimoh, A., 1989. The Monetary approach to the balance of payments: evidence from Nigeria, Seminar paper in the Faculty of Business and Social Sciences, University of Ilorin, Ilorin

Johnson, H.G.,1972. The case for flexible exchange rate 1969. In H.G. Johnson, Further Essays in Monetary Economics. London: Allen \& Unwin

Keynes, J.M.,1936. The general theory of employment, interest and money. London: Macmillian

Koutsoyiannis, A., 1977. Theory of econometrics, Basingstoke: Macmillan press ltd

Levacic R. and Rebmann A., 1982. Macroeconomics, London and Babingstoke, Macmillan publishers.

Meade, J.E., 1951. The theory of international economic policy, vol 1, London: Macmillian

Meade, J. (1978). The meaning of" internal balance". The Economic Journal, 423-435. http://dx.doi.org/10.2307/2232044

Mundel, R.A., 1962. The Appropriate use of external and internal stability, IMF Staff papers http://dx.doi.org/10.2307/3866082

Mundel, R. A., 1963. International economics. New York: Macmillian

Oluleye, F.A., 2005. Unemployment and inflation: An empirical investigation of the validity of phillips relation in Nigeria, Nigerian Journal of Monetary Economics, (4-5):104-117

Oluleye, F.A., 2008. Determinants of consumption expenditure in Nigeria. Unpublished Doctoral thesis, University of Portharcourt, Nigeria

Oyeniyi, T.A., 1997. Fundamental principles of econometrics, Lagos, Cedar Group (Nig) Ltd.

Parkin M., 1998. Economics, Addison-Wesley Publishing Company Inc.

Sodersten, B., 1980. International economics.London: Macmillian

Solow, R., 1969. Price expectations and the behaviour of the price level, Manchester: University Press

Udu, E and Agu, G.A., 1989.Economics, Onitsha: Africana-FEP Publishers Ltd.

\section{Appendix}

Identification Status of the Model

The derived model of the study is:

$$
\begin{aligned}
& \mathrm{Y}=\mathrm{f}(\mathrm{i}, \mathrm{e}, \mathrm{u}) \\
& \mathrm{CA}=\mathrm{f}(\mathrm{e}, \mathrm{Y}, \mathrm{u}) \\
& \Pi=\mathrm{Y}=\mathrm{CA}
\end{aligned}
$$


This model is complete in that the number of endogenous variables is equal to the number of equations. To identify this model, two conditions must be met: Order and Rank conditions.

Order condition:

$$
(\mathrm{K}-\mathrm{M}) \geq(\mathrm{G}-1)
$$

Where $\mathrm{K}=$ total number of variables in the model

$\mathrm{M}=$ number of variables in a particular equation

$\mathrm{G}=$ total number of equations

Equation 1: $(5-3) \geq(3-1) » 2=2$ exactly identified

Equation $2:(5-3) \geq(3-1) \quad$ $2=2$

Equation $3:(5-3) \geq(3-1)$ » $2=2$

\section{Rank condition:}

This condition states that for an equation to be identified, it must be possible to construct at least one non-zero determinant of order G-1 from the coefficients of the variables excluded from the particular equation but included in other equations of the model.

From equations 1, 2 and 3 above, we have:

$$
\begin{aligned}
& \mathrm{Y}=\mathrm{Y}_{0}+\mathrm{Y}_{1} \mathrm{e} \\
& \mathrm{CA}=\mathrm{CA}_{0}-\mathrm{CA}_{1} \mathrm{Y} \\
& \Pi=\prod_{0}-\prod_{1} \mathrm{CA}
\end{aligned}
$$

This model can be rewritten as:

$$
\begin{aligned}
& -\mathrm{Y}+\mathrm{Y}_{0} \mathrm{i}+\mathrm{Y}_{1} \mathrm{e}+0 \prod+0 \mathrm{CA}=0 \\
& -\mathrm{CA}_{1} \mathrm{Y}+0 \mathrm{i}+\mathrm{CA} \mathrm{A}_{0} \mathrm{e}+0 \prod-\mathrm{CA}=0 \\
& \prod_{0} \mathrm{Y}+0 \mathrm{i}+0 \mathrm{e}-\Pi-\prod_{1} \mathrm{CA}=0
\end{aligned}
$$

From the above, we can form a table of structural parameters as follows:

\begin{tabular}{cccccc}
\hline Equation & \multicolumn{5}{c}{ Variable } \\
\hline Equation 1 & $\mathrm{Y}$ & $\mathrm{i}$ & $\mathrm{e}$ & $\Pi$ & $\mathrm{CA}$ \\
\hline Equation 2 & -1 & $\mathrm{Y}_{0}$ & $\mathrm{Y}_{1}$ & 0 & 0 \\
Equation 3 & $\prod_{0}$ & 0 & $\mathrm{CA}_{0}$ & 0 & -1 \\
\hline
\end{tabular}

Table of excluded variables for equation 1

Note: Order $\mathrm{G}-1=2 \quad|\mathrm{~A}|=-1$

\begin{tabular}{ll}
\hline$\Pi$ & CA \\
\hline 0 & -1 \\
\hline-1 & $-\prod_{1}$ \\
\hline
\end{tabular}

Table of excluded variables in equation 2

\begin{tabular}{lll}
\hline & i & $\prod$ \\
\hline $\mathrm{Y}_{0}$ & & 0 \\
\hline 0 & & -1 \\
\hline
\end{tabular}

Note: Order $\mathrm{G}-1=2 \quad|\mathrm{~A}|=-\mathrm{Y}_{0}$

Table of excluded variables in equation 3

\begin{tabular}{ll}
\hline $\mathrm{i}$ & $\mathrm{e}$ \\
\hline $\mathrm{Y}_{0}$ & $\mathrm{Y}_{1}$ \\
\hline 0 & 0 \\
\hline
\end{tabular}

Note: Order G-1 $|\mathrm{A}|=\mathrm{Y}_{0} \mathrm{CA}_{1}$

It is obvious from the above that there is at least one non-zero determinant in each of the equations. Hence, from the above analysis, our model is identified implying that it is possible to derive unique estimates of the parameters. 